\title{
Moldova: Institutions Under Stress-The Past, the Present and the Future of Moldova's Higher Education System
}

\author{
Lukas Bischof and Alina Tofan
}

\section{INTRODUCTION}

This chapter introduces the higher education system (HES) in the Republic of Moldova and discusses the changes it underwent between 1991 and 2015. The case of Moldova is characterised by competing forces such as the oscillating political priorities of often-changing governments, labour market changes, emigration and demographic decline. Political blockades and interdependences in such a small country have only allowed hesitant consolidation of the higher education system.

\section{Bischof $(\square)$}

Institute of Education, Higher School of Economics, Moscow, Russia Graduate School of Global Studies, University of Leipzig, Leipzig, Germany

A. Tofan

University Leipzig, Leipzig, Saxony, Germany

(c) The Author(s) 2018

J. Huisman et al. (eds.), 25 Years of Transformations of Higher

Education Systems in Post-Soviet Countries, Palgrave Studies in Global

Higher Education, https://doi.org/10.1007/978-3-319-52980-6_12 


\section{The Republic of Moldova}

The Republic of Moldova is a post-Soviet state, situated between Romania and Ukraine, with a long and controversial history of shifting borders and a short history as an independent state. Regarding higher education, the quasi-permanent peripheral status the region had for centuries was not favourable to the establishment of centres of higher learning before the mid-twentieth century.

The territory of modern-day Moldova between the area's two main rivers, the Dniester and the Prut, was part of a Romanian principality (Principality of Moldova) from 1359 until 1538, when it became a vassal state of the Ottoman Empire. In 1812, the Russian Empire annexed the eastern part of medieval Moldova from the Ottoman Empire and renamed the annexed region "Bessarabia". After World War I, the area became part of the Romanian State until the German-Russian non-aggression pact allowed the Soviet Union to re-annex Bessarabia in June 1940. In August 1940, the Soviet authorities created the Moldovan Soviet Socialist Republic (MSSR), encompassing mostly the interwar Bessarabia annexed territory as well as a strip of land on the eastern bank of the Dniester from an earlier-established "Moldavian SSAR". Simultaneously, the southern and northern areas of Bessarabia and almost $60 \%$ of the MSSR territory were incorporated into Ukraine. In addition to reconfiguring the ethnic and linguistic landscape of the MSSR in this way, the Soviet government sought to reshape the identity of the republic's remaining population through the creation of a distinct national Moldovan identity. On the one hand, this presupposed a distinctive "Moldovan" language with Cyrillic letters, distinct and separate from the Romanian language. On the other, Russian was imposed as the predominant language at all levels of social organisation. This process was not specific to the Republic of Moldova, but part of the much larger Sovietisation taking place across the Soviet Union (Worden 2014, 49).

The Republic of Moldova became independent from the Soviet Union in 1991, retaining its Soviet-defined borders. During the dissolution of the USSR, the region on the eastern bank of the Dniester with its predominantly Russian-speaking population self-proclaimed an independent "Pridnestrovian Moldavian Soviet Socialist Republic" (Transnistria) in 1990; its capital was located in Tiraspol. In 1992, the political tension degenerated into a military engagement and evolved into a frozen conflict. As of 2015, the Moldovan government still has no control over the 
territory and higher education in Transnistria will not be addressed in this chapter. The total population of Moldova within its internationally recognised borders was 3,940,000 in 2014 (National Bureau of Statistics of the Republic of Moldova 2014) with 78\% Moldovan/Romanian, followed by Ukrainian (8\%), Russian (4\%), Gagauz (4\%) and Bulgarian (2\%).

\section{Higher Education in THE MSSR}

The history of higher education in the modern Republic of Moldova is relatively young, the bulk of its development occurring during the Soviet period with support from professors from Leningrad, Odessa, Kiev and Moscow (Tiron et al. 2003, 23). As in other Soviet republics, not only were the HES organisational structure and governance arrangements of the USSR replicated in Moldova but also the contents of the courses, study programmes, teaching methods and recruitment policies. The lack of academic traditions prior to the Soviet period and the import of established Soviet institutional types (as well as staff) into Moldova accentuated the typical characteristics of the Soviet educational system in the Moldovan case. The immigration of professors and scientists from other Soviet republics, especially Russia and Ukraine, raised the educational levels of the population but also promoted the use of the Russian language, which became the predominant language of education. ${ }^{1}$ By 1988 the HES of the MSSR included nine state HEIs (Yagodin 1990, 76): one university, seven specialised institutes (three pedagogical institutes, one medical institute, one technical institute, one agricultural institute and one art institute) as well as one conservatory (Table 12.1).

On the one hand, ample state funding to HEIs created unprecedented growth and "a 'golden' period in the development of Moldavian cultural life" (Padure 2009, 234), a well-developed technical and material base (Stati 2002) and internationally comparable educational standards (Cojocaru 1995, 74). On the other hand, the high centralisation of the Soviet educational system made it static and unable to adequately respond to the changing needs of the dynamic labour market (Smolentseva 2012, 16-17). The strict centralisation of education led to the bureaucratisation of management, authoritarianism, excessive uniformity, a lack of understanding of local conditions, a stifling of "bottom up" initiatives (Cojocaru 1995, 74), and a lack of academic mobility (Galben and Cogan 2003; Padure 2009). Participation in HE was still the third lowest of all Soviet republics (Yagodin 1990). 
Table 12.1 HEIs in Moldova during the Soviet period

\begin{tabular}{|c|c|c|c|c|}
\hline Year & Name & Location & Profile & $\begin{array}{l}\text { Number } \\
\text { of students } \\
\left({ }^{\prime} 91 /{ }^{\prime} 92\right)\end{array}$ \\
\hline 1926 & $\begin{array}{l}\text { Moldavian Institute of Public } \\
\text { Education in Tiraspol }\end{array}$ & Tiraspol & Teacher training & 2,720 \\
\hline 1940 & $\begin{array}{l}\text { Agricultural Institute in Chisinau, based } \\
\text { on pre-existing Agronomy Department } \\
\text { at the University of Iasi }{ }^{{ }^{a}}\end{array}$ & Chisinau & $\begin{array}{l}\text { Agricultural } \\
\text { education }\end{array}$ & 4,220 \\
\hline 1940 & $\begin{array}{l}\text { Pedagogical State Institute "Ion } \\
\text { Creangă” Chisinau }\end{array}$ & Chisinau & Teacher training & 4,335 \\
\hline 1940 & $\begin{array}{l}\text { State Conservatory in Chisinau, based } \\
\text { on pre-existing Chisinau "Unirea" } \\
\text { Conservatory }\end{array}$ & Chisinau & Musical education & 2,017 \\
\hline 1945 & $\begin{array}{l}\text { The State Medical Institute as a } \\
\text { successor of Medical Institute No.1 in } \\
\text { St. Petersburg }\end{array}$ & Chisinau & $\begin{array}{l}\text { Medicine and } \\
\text { pharmacy }\end{array}$ & 5,113 \\
\hline 1945 & $\begin{array}{l}\text { The Pedagogical Institute of Balti, } \\
\text { based on the Primary School Teachers } \\
\text { Institute in Balti (1945) and renamed } \\
\text { in } 1959 \text { to "Alecu Russo Balti State } \\
\text { Pedagogical Institute" }\end{array}$ & Balti & Teacher training & 4,030 \\
\hline 1946 & $\begin{array}{l}\text { The Chisinau State University, } \\
\text { integrating the Chisinau-based } \\
\text { Departments of the Moscow } \\
\text { Economics Institute and the Moscow } \\
\text { Institute for Legal Studies in } 1953 \text { and } \\
1959\end{array}$ & Chisinau & $\begin{array}{l}\text { Classical } \\
\text { comprehensive } \\
\text { university }\end{array}$ & 6,015 \\
\hline 1946 & $\begin{array}{l}\text { Moldovan Affiliate for Scientific } \\
\text { Research of the Academy of Sciences of } \\
\text { the USSR (1949 converted into } \\
\text { Moldovan Branch of the Academy of } \\
\text { Sciences of the USSR, and in } 1961 \\
\text { reorganised as the Academy of Sciences } \\
\text { of MSSR) }\end{array}$ & Chisinau & Research institute & $\mathrm{n} / \mathrm{a}$ \\
\hline 1963 & Moldavian State Institute of Arts & Chisinau & $\begin{array}{l}\text { Belle arte } \\
\text { education }\end{array}$ & 2,158 \\
\hline 1964 & $\begin{array}{l}\text { The Polytechnic Institute in Chisinau, } \\
\text { which emerged from the Faculties of } \\
\text { Engineering and Economics at } \\
\text { Chisinau State University }\end{array}$ & Chisinau & $\begin{array}{l}\text { Technical } \\
\text { education }\end{array}$ & 9,765 \\
\hline
\end{tabular}

${ }^{a}$ The Agrarian University became the only institution with "all-Union significance" (Vsesoyuznogo znacheniya) in the MSSR. The other HEIs educated specialists primarily for the local labour market. 


\section{Transformation of the Higher Education System in the Republic of Moldova}

The Republic of Moldova declared its independence on 27 August 1991. This marked the beginning of radical political, economic and social changes aiming at developing a market economy based on private and public property, entrepreneurship and competition. As a consequence, the political, economic and social changes also created the necessity to align the social and educational institutions the young country had inherited from the Soviet Union.

As did other countries, Moldova faced the multiple challenges of maintaining and building a self-sufficient HE system in a small country under the conditions of a rapidly deteriorating planned economy. Challenges also included adapting the higher education system to support nation and state building as well as harmonising the education system with European and international practices. These sometimes competing objectives all shaped the transition process, which did not turn out to be a smooth one.

Indeed, compared to the neighbouring post-Socialist states in terms of HE expansion and diversification, curricula de-ideologisation, governance democratisation and European integration in the Republic of Moldova, the transition from the Soviet system to a distinct national HES occurred in several abrupt and often contradictory steps, with policy shaped by often-changing governments and education ministers. Educational policy was thus often subject to contradictory oscillations between the divergent political vectors in language politics (pro-Romanian vs. pro-Russian) and ideological orientation (pro-Communist and pro-Western) (Padure 2009, 335-37) (Fig. 12.1).

The following timeline gives an overview of important steps in the development of the HES in the Republic of Moldova.

The development and institutional diversification of the HE system in Moldova are characterised by the direct involvement of the main political forces; the parliament of the Republic of Moldova was a strong driving force shaping the higher education system. The many changes of parties in power were thus reflected in different policy initiatives promoted by parliament, which reflected the different political factions in power during each phase.

The first post-Soviet years (1989-1994) were characterised by conceptualisation, experimentation and the emergence of private $\mathrm{HE}$ in a young independent republic. Until 1989, all HEIs in the MSSR were state institutions exclusively funded by the state. In 1989, the first groups of students 


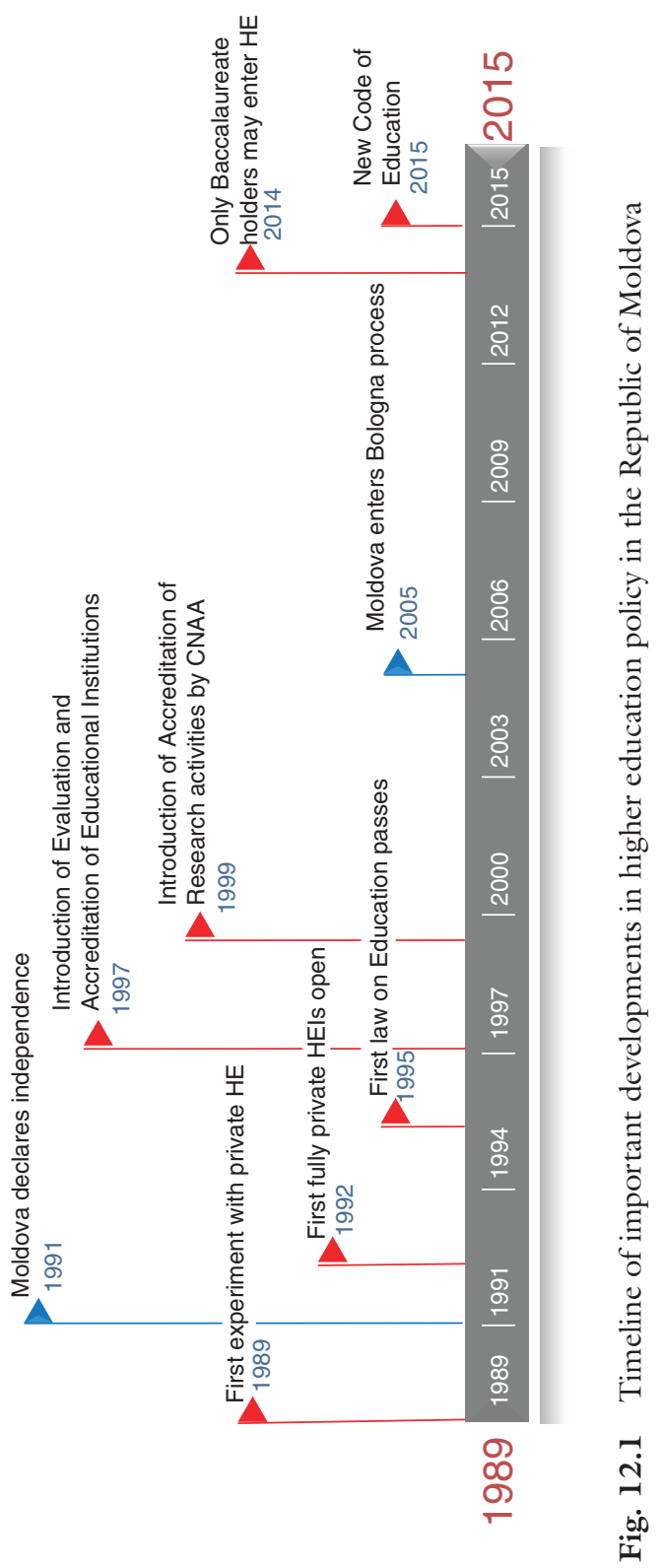


were enrolled on a tuition basis in a special English-language engineering and technical programme designed as a private entity within existing state institutions at the Polytechnic Institute in Chisinau. ${ }^{2}$ In September 1992, the first two private educational institutions opened their doors in Chisinau almost simultaneously: the University of Humanities and the Free International University of Moldova (Galben and Cogan 2003, 28-30). This marked the actual start of an institutional diversification process of the national higher education system. Prior to the 1995 Law on Education, private HEIs operated based on the Soviet Law of Education (1972, repealed in 1992) along with government decisions.

The development of a new conceptual and legal framework for the national HE system began with the Concept on the Development of Education in the Republic of Moldova (1994) and the Law on Education (The Parliament of the Republic of Moldova 1995) which established postSoviet educational policy and regulated the organisation and functions of national education. Especially during the 1990s, higher education reforms were often modelled on Romanian examples. ${ }^{3}$ Moldova's ascension to the Bologna Process and the European Higher Education Area (EHEA) in 2005 marked the beginning of the gradual integration of the Moldovan HES into the European area. As summarised by Ciurea, Berbeca, Lipcean and Gurin (2012), reforms aimed at three priority areas: (1) changing the structure of the university system, organising higher education in three cycles, introducing the diploma supplement and the European Credit Transfer and Accumulation System; (2) organising an internal and external quality evaluation and monitoring system by creating a quality assurance agency independent of the government, and quality management centres at each university; and (3) connecting the university curricula to the market by tracing graduate employment, creating links with employers and professionalising education. While most actors welcomed the accession to the European Higher Education Area, the related action programme proved to be a serious challenge. This was the implementation of broad structural reforms in financing, quality assurance, stricter regulation of access to $\mathrm{HE}$, greater institutional autonomy, the development of a national qualification framework and the elaboration and adoption of a new legal framework for higher education (Code of Education).

In summary, the Republic of Moldova is a country which essentially did not have an HES prior to its establishment by the Soviet Union and inherited its institutional architecture. For almost two decades, the country perpetuated many Soviet HES institutional arrangements, first of all centralised governance (Toderaş 2012). The following sections describe 
the key structural changes in the Moldovan higher education system between 1989 and 2015 .

\section{Structure, Change and Continuity of the Higher Education System in Moldova}

\section{Degree Structure}

After joining the Bologna Process in 2005, Moldova reorganised its former Soviet-style degree structure into a two-cycle degree system (Turcan et al. 2015, 19), consisting of Bachelor (3-4 years) and Master's degrees (1-2 years). This was accomplished by 2011 . Only medical, pharmaceutical and architectural education retain their one-tier structure. Study programmes can be organised as day, evening or extramural. The new Code of Education (2014) extends the tertiary education cycles and introduces cycle III: Higher Education PhD. Within cycle III, the Soviet "kandidat" and "doktor nauk" degrees are still in place as "Doctor" and "Doctor Habilitate".

\section{Classification of HEIs}

By law, Moldovan HEIs are classified by ownership as either public or private and, as unchanged since the Soviet era, by the scope of their disciplinary offers as universities, academies or institutes. However, between 1990 and 1999 as an attempt to restructure and optimise the HE landscape in accordance with new social and economic needs, almost all public specialised HEIs (institutes) were converted into "classical universities" with the possibility to offer study programmes outside their previous area of specialisation. ${ }^{4}$ Newly founded regional public universities (in Comrat, Taraclia, Cahul) were designed as classic universities from the beginning. The only exceptions were the new public specialised HEIs, which were founded to serve the needs of state building, especially for international relations, police and armed forces.

With the exception of the University of the Academy of Science, the different types of HEIs are considered equal in terms of academic organisation, governance and state standards and requirements. All HEIs are coordinated by the Ministry of Education. Since Soviet times, each HEI has been affiliated to and supervised by a particular ministry. For the vast majority of HEIs, this is the Ministry of Education. Specialised universities and 
academies are affiliated to other ministries (e.g., the State University of Medicine and Pharmacy reports to the Ministry of Health, the State Agrarian University to the Ministry of Agriculture and Food Industry, and the Academy of Public Administration to the President of the Republic of Moldova). However, the Ministry of Education still remains their institutional supervisor for education and research activities. As with the official classification, the ministry affiliation in itself does not have an effect on status or reputation.

\section{Admission to Higher Education}

For each state university and for all study cycles, the government sets admission quotas for state-funded (budgets) and tuition-based study places. Competition for admission is based on grades achieved during and at the end of secondary education (Baccalaureate exams). Depending on the number of study places determined by the state and the score obtained on school leaving certificates, applicants can either enrol in state-funded or tuition-based places. The share of state-funded places is considerably smaller; about one-third of students are financed by the state, whereas the rest pay tuition fees (self-financed) (Ruffio et al. 2012). The entrance regulations are the same for private and public HEIs.

Until 2014, admission to higher education was possible for graduates from different secondary education schools including lyceums, general schools and vocational schools and colleges. Since 2014, however, the exclusive entry requirement is the Baccalaureate Diploma issued by lyceums. ${ }^{5}$ This restricts the number of eligible potential students for HEIs and has had an effect on admission numbers (Fig. 12.3).

\section{The Development of the Public and Private HE Sector}

As of 2015/2016, there are 30 HEIs in operation in Moldova, 19 of them state institutions and 11 private institutions. The development of private higher education as an alternative to state education started in 1992 with the inauguration of two classic (humanistic) universities. In 2000, the number of private HEIs had risen to 32 compared to only 15 public institutions. The lack of a stringent quality assurance system allowed universities to multiply (especially private HEIs) and significantly internally expand (especially state HEIs). Expansion was greatest for HEIs benefitting from preferential allocations or on the basis of political affinity (as in the case of ASEM or Institute of International Relations of Moldova (IRIM)) or political 


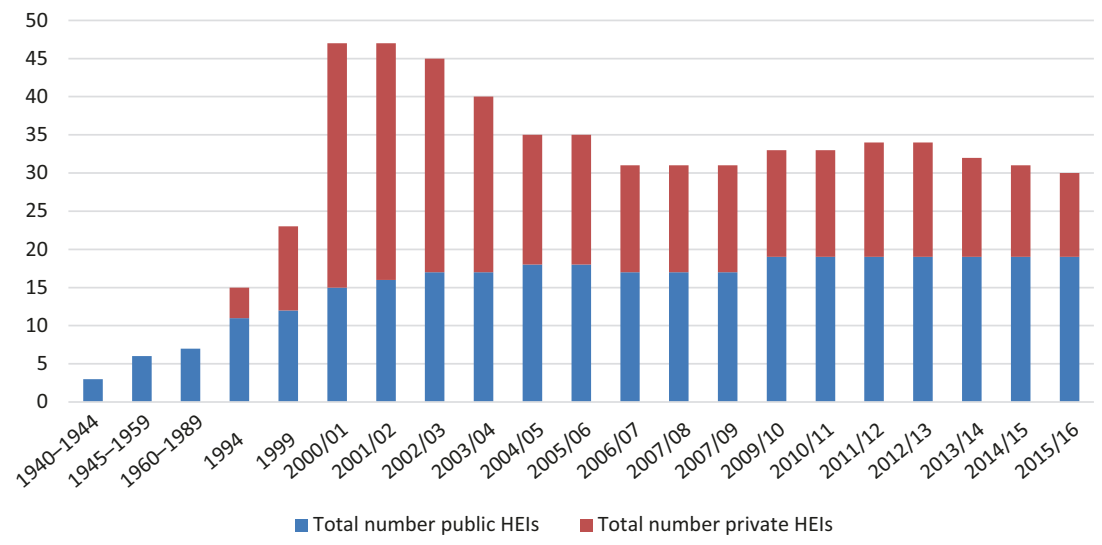

Fig. 12.2 Number of public and private HEIs in the Republic of Moldova

centrality (as with the University of the Academy of Science). During the 2000 s this number was substantially reduced again when many private HEIs failed to survive the intermittent economic crisis and the competition with the public education sector, in which they were at a disadvantage.

The emergence in the 1990s of private $\mathrm{HE}$ as an alternative to public HE was a response to the pressures of socioeconomic and political demand and new opportunities at a time of rapid economic and social change. The institutional mission of the first private HEIs was to train specialists for the market-oriented economy and under (new) conditions of the marketoriented economy. Over the years, the environment which generated HES transformations has changed, as has the strategic focus of many private HEIs. Only one private HEI (The Free International University of Moldova) corresponds to the profile of a "classical" comprehensive university. The rest of the private sector seems to be guided primarily by economic considerations, which seem to be the decisive factor in establishing new graduate degree programmes.

"Public" HEIs, however, also changed their behaviour in similar ways to the non-public HEIs. The Law on Education (1995) stipulated that state education is generally tuition-free ("free of charge"), but insufficient state funding has in fact forced HEIs to find new income sources to fill this gap (Secrieru 2007, 12-14). State HEIs have accomplished this since 


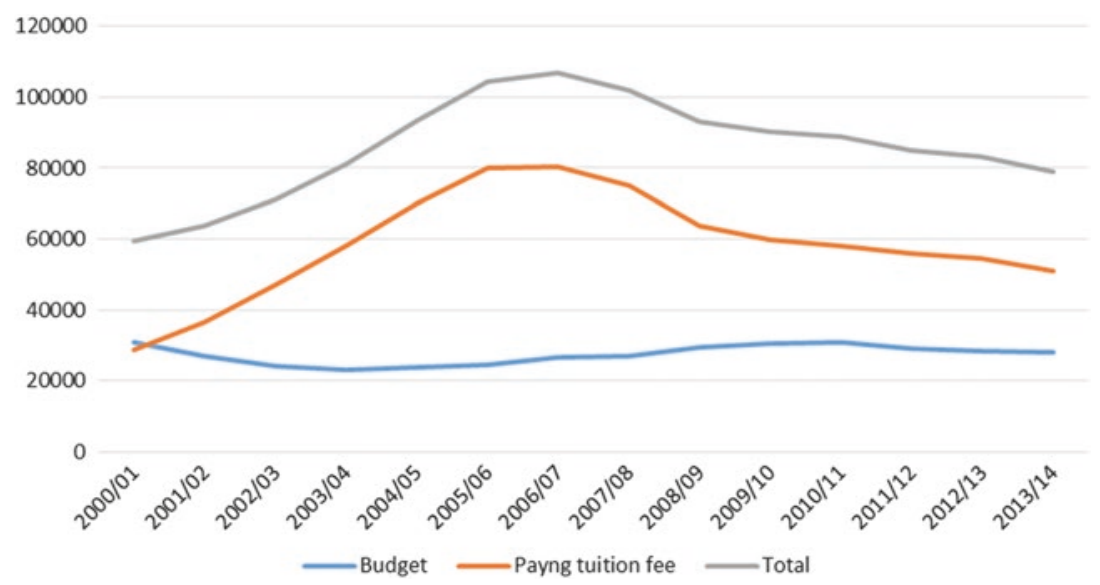

Fig. 12.3 Development of the total number of students enrolled on a budget and tuition-fee basis (in both private and public HEIs)

1993-1994 by enrolling students on a "contract basis", which requires those students to pay tuition fees. The following graph illustrates these developments (Fig. 12.3):

While the law distinguishes HEIs by ownership status, higher education policy requires private HEIs to fulfil the same criteria as public HEIs. Private HEIs are subject to the same accreditation requirements as public institutions and have to conform to the same admission regulations. In the 2013-2014 academic year, private HEIs in Moldova made up $39 \%$ of the total number of HEIs while only enrolling around $20 \%$ of all students. Their role is thus relatively modest. Their emergence, however, represents an important increase in the institutional differentiation of the Moldovan HES.

\section{Differentiation of HEIs Based on Research Activity}

Another "historical" legacy of the Soviet Union is the perception of universities as primarily teaching institutions, leaving research to the Academy of Science. The one exception to this rule is the University of the Academy of Science itself, which was founded with the express objective of conducting both teaching and research. This, however, does not mean that its 
reputation within the HE system is better than that of other HEIs. Until 2014, doctoral studies at other universities always depended on the Academy of Science for examination and oversight and were tolerated rather than welcomed at universities. To what degree the new Law on Education of 2014 will change this remains to be seen.

Moldovan HEIs report a relatively large volume of annual scientific production to the Ministry of Education. Most of this data, however, is published in local journals and collections; to the authors' knowledge, there is no database for a reliable comparative analysis of research productivity or funding. The non-inclusion of most local publications in international databases (ISI-Thomson and Scopus) means they are mostly invisible to the international scientific community (Cuciureanu 2014, 63). As a consequence, Moldovan HEIs are currently not represented in the internationally recognised rankings by Academic Ranking of World Universities (ARWU), THE, Quacquarelli Symonds World University Rankings (QS), University Ranking by Academic Performance (URAP) and CWTS Leiden. An indication for research performance is accreditation by the National Council of Attestation and Accreditation (CNAA), which conducts an assessment of HEI research activity and acts as a precondition to receiving public funding for research. ${ }^{6}$ Of 30 HEIs in the Republic of Moldova, currently only 14 public universities and 4 private universities have been accredited by the CNAA and may thus receive public funding for research. Since the new Code of Education (2014), PhD programmes need to be conducted in doctoral schools, which need to be accredited. As of November 2015,43 doctoral schools had received temporary authorisation. Of all 30 Moldovan HEIs, only the 18 with CNAA accreditation were permitted to establish doctoral schools. All but two of these are located in Chisinau. ${ }^{7}$

\section{International Cooperation}

There is an ongoing process of differentiation between Moldovan HEIs in terms of international activities. While some HEIs (especially USM, UTM, USMF, ULIM, UPS and the Agrarian University) are actively developing internationalisation activities, the HES overall is still very weakly internationalised (Cuciureanu 2014, 63). While the number of foreign students reached a low point in 2008/2009 and has since been increasing again, the overall share of foreign students remains around $2 \%$ and the number of teachers from abroad remains insignificant. 


\section{Typology of HEIs in the Republic of Moldova IN 2015}

Although all HEIs operate under the same legal framework, their status, quality and performance vary. This variation exists in regard to accreditation status, size (in terms of number of students and staff), the degree of research activities, the level of international activities and, as a result of these factors, financial situation. Based on size (in terms of student number), scope (in terms of study programmes), research activity, prestige and internationalisation as discussed above, a number of distinct types of Moldovan HEIs can be distinguished (Table 12.2) ${ }^{8}$.

The large high-prestige comprehensive universities (type I) have developed a good reputation in teaching and partially in research. They also have developed infrastructure and a collective of teachers. Except for two (The Free International University of Moldova and the Academy of Economic Studies of Moldova), all of them already existed before 1991. This historical heritage combined with their mostly public status and government education policies favoured their development during the postSoviet period. All of them have active doctoral schools, are accredited by CNAA in different research areas and are partners in various regional or international academic cooperation projects. Over two-thirds of all students are enrolled at these universities. Except for one (Balti), all are located in the capital city of Chisinau.

Specialised middle- to high-prestige universities (type II) offer high-quality study programmes in a small range of subjects such as medicine, economics or the arts. These universities have managed to develop a good reputation in their respective fields. All of them have active doctoral schools, are accredited by CNAA in specific research areas and are partners in various regional or international academic cooperation projects. All of them are located in the capital city of Chisinau.

Between 1991 and 2004, three regional public universities were founded in small cities in the south (type III). Only about 3\% of all Moldovan students study at the newly established regional universities in Cahul (1.6\%), Comrat (1.8\%) and Taraclia (0.28\%). These type III HEIs are characterised by a small number of students (between 300 and 700 in total), a reduced range of studies and relatively little research; their longterm survival has been put into question (Turcan and Bugaian 2015). 
Table 12.2 Types of HEIs in 2015

\begin{tabular}{|c|c|c|c|}
\hline Type/label & \# & HEIs in this category & Description \\
\hline $\begin{array}{l}\text { I. Large high-prestige } \\
\text { comprehensive } \\
\text { universities }\end{array}$ & 8 & $\begin{array}{l}\text { Moldova State University, } \\
\text { Technical University of Moldova, } \\
\text { Free International University of } \\
\text { Moldova, Academy of Economic } \\
\text { Studies of Moldova, State Agrarian } \\
\text { University of Moldova, Chisinau } \\
\text { Pedagogical State University "Ion } \\
\text { Creanga", Tiraspol State } \\
\text { University, Balti "Alecu Russo" } \\
\text { State University }\end{array}$ & $\begin{array}{l}5 \mathrm{k}+\text { students, large } \\
\text { number of study } \\
\text { programmes, developed } \\
\text { infrastructure, good } \\
\text { international contacts } \\
\text { and partnerships, public } \\
\text { or private, doctoral } \\
\text { programmes }\end{array}$ \\
\hline $\begin{array}{l}\text { II. Specialised } \\
\text { middle- to high- } \\
\text { prestige universities }\end{array}$ & 6 & $\begin{array}{l}\text { European University of Moldova, } \\
\text { "Constantin Stere" University of } \\
\text { European Political and Economic } \\
\text { Studies, Trade Co-operative } \\
\text { University of Moldova, State } \\
\text { University of Medicine and } \\
\text { Pharmacy "N.Testemiteanu", } \\
\text { Academy of Music, Theatre and } \\
\text { Fine Arts, State University of } \\
\text { Physical Training and Sports }\end{array}$ & $\begin{array}{l}\text { Large number of } \\
\text { specialised study } \\
\text { programmes, developed } \\
\text { infrastructure, good } \\
\text { international contacts } \\
\text { and partnerships, public } \\
\text { or private, doctoral } \\
\text { programmes }\end{array}$ \\
\hline $\begin{array}{l}\text { III. Regional public } \\
\text { universities founded } \\
\text { after independence (in } \\
\text { Comrat, Cahul, } \\
\text { Taraclia) }\end{array}$ & 3 & $\begin{array}{l}\text { Cahul State University "Bogdan } \\
\text { Petriceicu Hasdeu”, Comrat State } \\
\text { University, Taraclia "Grigore } \\
\text { Țamblac" State University }\end{array}$ & $\begin{array}{l}\text { Small number of } \\
\text { students, reduced range } \\
\text { of study programmes } \\
\text { and a predominantly } \\
\text { regionally oriented } \\
\text { teaching activity }\end{array}$ \\
\hline $\begin{array}{l}\text { IV. Highly specialised } \\
\text { state HEIs }\end{array}$ & 5 & $\begin{array}{l}\text { Academy of Transports, Computer } \\
\text { Sciences and Communications, } \\
\text { Military Academy of the Armed } \\
\text { Forces "Alexandru cel Bun", } \\
\text { Academy of Public Administration; } \\
\text { The Academy "Stefan cel Mare" of } \\
\text { Minister of Internal Affairs, } \\
\text { Institute of International Relations } \\
\text { of Moldova }\end{array}$ & $\begin{array}{l}\text { Specific affiliation to a } \\
\text { particular ministry, } \\
\text { highly specialised study } \\
\text { programmes to meet } \\
\text { demand of state services }\end{array}$ \\
\hline V. Small private HEIs & 4 & $\begin{array}{l}\text { University "Perspectiva-INT", } \\
\text { Institute of Applied Criminology } \\
\text { and Criminal Sciences of Moldova, } \\
\text { Dniestr University of Economics } \\
\text { and Law, University "Higher } \\
\text { Anthropological School" }\end{array}$ & $\begin{array}{l}\text { Small number of } \\
\text { students, reduced range } \\
\text { of cost-effective study } \\
\text { programmes }\end{array}$ \\
\hline
\end{tabular}


Table 12.2 (continued)

\begin{tabular}{lll}
\hline Type/label & $\#$ HEIs in this category & Description \\
\hline VI. Special HEIs & $4 \begin{array}{l}\text { IMI-Nova International } \\
\text { Management Institute, Slavonic } \\
\end{array}$ & $\begin{array}{l}\text { Very specific profile, } \\
\text { unique HEIs } \\
\text { Sciences, University of the } \\
\text { Academy of Science }\end{array}$ \\
& & \\
\hline
\end{tabular}

Type III institutions were established to serve regional labour market needs and linguistic particularities (in the case of Taraclia).

There are five highly specialised state HEIs (type IV). These were founded with the objective of educating future staff for governmentrelated institutions such as the Ministry of Internal Affairs (Academy of the Ministry of Internal Affairs), Ministry of Foreign Affairs (Institute of International Relations of Moldova), the armed forces (Military Academy of the Armed Forces "Alexandru cel Bun") and the Academy of Science (University of the Academy of Science).

Of the 32 private HEIs that existed in 2000, only 11 survived. The remaining small private HEIs (type $\mathrm{V}$ ) play only a marginal role. They often struggle with lack of infrastructure (they often have to rent premises), a small number of students and the absence of research activity.

In addition to these HEIs, there are four with a unique profile which do not fit into any type. These special HEIs include two highly specialised institutions offering postgraduate education (the Academy of Public Administration (APA) trains civil servants and the Institute of Education Sciences conducts graduate research and training in education), as well as the University of the Academy of Science and the Slavonic University that offer study programmes in the Russian language.

\section{Forces Affecting the Development of the HES IN Moldova}

A number of forces have affected the development of the HES in the Republic of Moldova, which will be explored in this section. 


\section{Political Will to Break with the Soviet Past and Orientation Towards Romanian and European Models}

During the short history of the Republic of Moldova, political priorities have been oscillating between a strong orientation towards Romanian and Western models and more conservative tendencies in favour of preserving the model of higher education inherited from the Soviet Union. During the 1990s, higher education reforms were often modelled on Romanian examples. The tendency may have been promoted further by the substantial number of Moldovan students who have studied at Romanian universities since the 1990s. During the 2000s, the "European model of higher education" promoted by the Bologna Process became the most important point of reference for the public discourse on higher education reform, and European Union funded projects helped to introduce new curricula and management structures at many HEIs.

\section{Demands for New Skills (e.g. in Business, Economics, Political Science) and Shifting Employment Prospects}

An important factor driving the differentiation of curricula offered by Moldovan HEIs is market demand for new skills. This became particularly evident during the large wave of newly founded HEIs after 1992 (see Annex 6.1). Private HE pioneered the import of Western curricula while new public HEIs were primarily established to train public servants for the young state. Of the ten HEIs founded between 1990 and 1995, seven were focused on economics, business administration, law or political science. These new skills were in high demand and soon most HEIs adapted to market demand by offering their own study programmes in these sought-after disciplines.

On the other hand, the economic collapse of substantial parts of the industrial and agricultural base of the country led to a decline in student interest in studying exact sciences, agriculture, medicine and engineering. This was sometimes to the ruin of the involved faculties which further suffered from brain drain due to emigration of highly qualified specialists.

\section{Maintained Public Funding for Education}

As in other CIS countries, the break-up of the economy in the early 1990s decreased government revenues and in consequence the public 


\section{Education expenses from public budget}

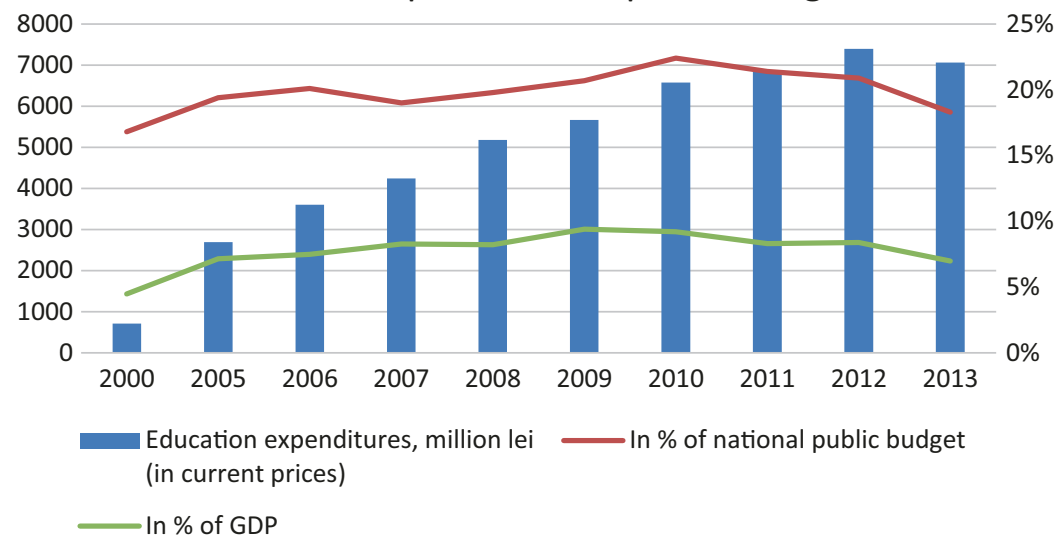

Fig. 12.4 Government expenditure on education 2000/2005-2013

funds available to HEIs (The World Bank 1997). On the other hand, public spending on education (as \% of GDP) is higher than in other postSocialist states, in fact, almost double the average of peer countries. Not only did Moldova establish and fund very small regional universities in cities such as Taraclia or Cahul; since 2000, Moldova has also increased spending on education each year, even in the face of a decreasing number of students. Without this continued public funding, several public HEIs may have disappeared, as did several private ones. While the survival of all public HEIs was assured, government funding was almost entirely subsistence-oriented and was used to pay for salaries and maintain existing infrastructure rather than investing in infrastructure quality and teaching staff. The following figure shows education funding in absolute and relative terms (Fig. 12.4).

\section{Demography, Stricter Admission Requirements and Attractive Alternatives Lead to Declining Student Numbers}

As described above, a demographic decline is reducing the number of potential students. In addition, reforms in secondary education have also had effects on the HES. The Code of Education (2014) enforced the Baccalaureate exam as a compulsory admission requirement, which has considerably reduced the number of potential students. In addition, an 


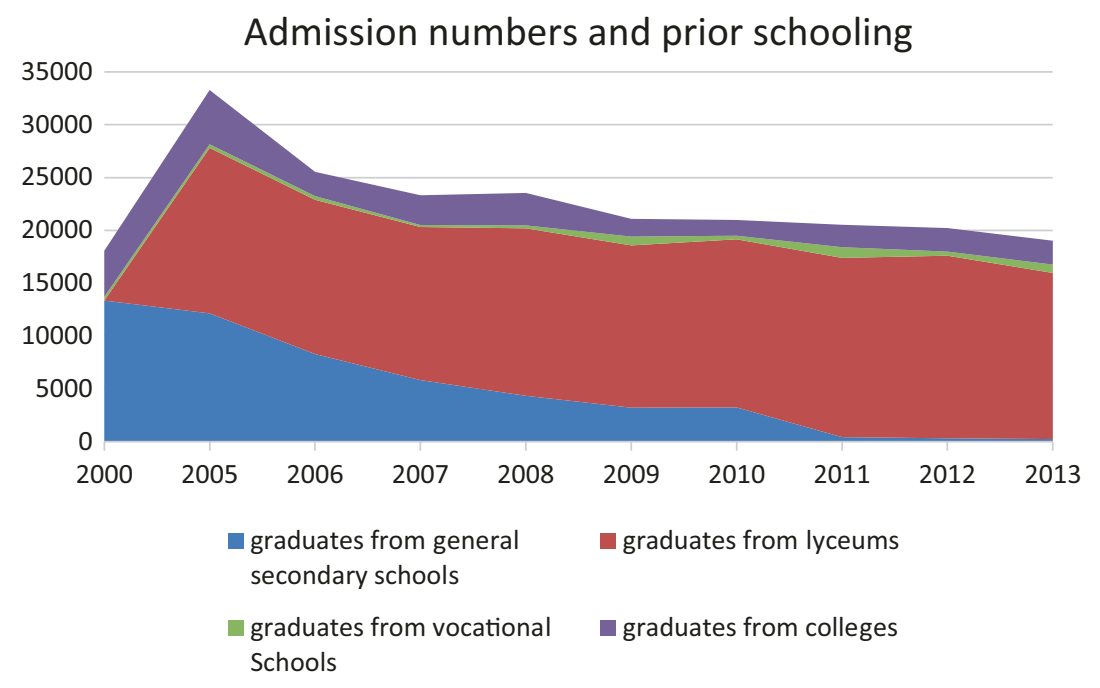

Fig. 12.5 Admission numbers by type of prior schooling (2000/2005-2013)

anti-fraud campaign conducted during the Baccalaureate exams in 2014 caused a sudden drop in the number of high school graduates who succeeded, resulting in a 2014 Baccalaureate pass rate of $56 \%$ compared to $96 \%$ in $2010 .{ }^{9}$ The following figure shows the decline in admission numbers by type of school leaving certificate (Fig. 12.5).

The HEI "crisis" due to lack of potential students is exacerbated by attractive alternatives to studying at home. Bilateral agreements and scholarship programmes with Romania, Russia, Ukraine, Bulgaria and Turkey are options for Moldavan students, mostly in specific ethnic groups. As of 2014 , over 4000 fully funded study places were open in Romania, 574 in Russia, 128 in Bulgaria and 100 in Ukraine. Scholarships for high school graduates are also provided by Turkey, Greece, China, Hungary, the Czech Republic, Slovakia and Lithuania. Moldovan graduates can continue their studies at universities in any country in the world, with the most preferred countries being Germany, Italy, France, the UK and the USA. According to mass media statistics, ${ }^{10}$ every year approximately 6000 young Moldovans are choosing to study abroad, although no official numbers seem to exist to confirm this. The demographic downshift has already led to the closing of two HEIs and is threatening many others. 
Internationalisation and Reform Driven and Supported by International Funding

Foreign funding has undoubtedly had an effect on the development of the higher education system in Moldova. Actors such as the Soros Foundation, the World Bank, the European Union, the Chinese government, the Council of Europe and others have provided funding for exchange programmes, scientific publications and conferences, as well as curricula modernisation and governance reform. While it is difficult to quantify the impact of these projects, their number, often-stated strategic purposes ${ }^{11}$ and feedback from personal communication make it reasonable to assume that they do indeed shape higher education policy.

The most visible impact of international funding has been the establishment of the International Management Institute "IMI-NOVA" in 1995 by USM, ASEM, ASM, Pierre Mendes University (Grenoble, France) and two large local Moldovan enterprises. The institute specialises in social sciences (law, international relations). It is active in various international partnerships, especially with the francophone world, and has introduced a double-degree programme which allows students to obtain a French as well as a Moldovan degree.

\section{Conclusions}

In summary, the development of the HES from its Soviet past can be described as a process of expansion and (still ongoing) consolidation. The 1990s were a time during which tremendous economic change (mostly decline) coincided with the sudden disappearance of governance structures (and indeed of government itself) that regulated and assured the quality of the higher education system. HEIs were faced with strong demand for new types of knowledge, while at the same time their ideological and economic foundations were in a state of rapid deterioration. Education entrepreneurs and (a little later) public HEIs took advantage of this situation by setting up new programmes and establishing new HEIs, which led to a tripling in the number of HEIs between 1989 and 1999. Not only newly founded HEIs but also established ones set up "trend" faculties teaching law, business administration, economics or international relations. Because of the speed of this expansion and the resulting scarcity of qualified teaching staff, HEIs often had to make do with less than qualified personnel. Student numbers soared, in part driven by a market need 
for the qualifications HEIs had to offer, in part for the prestige HE conferred on graduates and in part because the bleak economic situation offered few alternatives to young people. The lack of adequate state funding for HEIs created an incentive to attract and retain any fee-paying students while the lack of (rigorous) regulation made HE easy to enter, including for those who lacked the appropriate qualifications. As a consequence, the quality and, in turn, the reputation of HE began to suffer, in particular that of young HEIs in the provinces or non-publicly owned. Emigration of qualified teaching staff and the practice of teaching at more than one HEI for more income further contributed to this decline in quality.

The expansion phase reached a turning point around 2005. Several factors contributed to this, the most powerful of which is demography. The HES had expanded to such a degree that the available number of HEI study places had become saturated and even exceeded demand. On the other end of the supply-demand equation, high incidences of emigration and low birth rate led to a decline in the number of potential students. The state as a regulation agency had further consolidated structures and was implementing stricter forms of quality assurance; these were restricting the ability of sub-par HEIs, but also clamping down on corrupt practices in school-leaving and university entrance examinations, which were reducing the number of potential students. The poor reputation of some HEIs made them less attractive to students eligible for $\mathrm{HE}$ with increasing opportunity to choose between affordable options, not only in Moldova but also abroad. The consequences of declining student numbers have long been visible in the declining number of private HEIs, while public HEIs have so far been kept alive by maintained state funding. ${ }^{12}$

Comparing the situation in 1991 and 2015, one cannot help but note that the Soviet-era institutions still form the core of the HE system. Only two truly new HEIs have grown to resemble the "old" institutions in terms of size, scope and quality, while most newer HEIs are smaller and focus on serving the regions or very specific market niches and make up only a small part of the higher education system.

The demographic and economic situation makes it unlikely that all HEIs will continue to thrive or even survive in their present form. In some cases, they may disappear altogether. HEIs with the least fortunate geographical and demographic potential in the regions as well as those with the worst reputations will likely be hardest hit. More fortunate HEIs may be facing fiercer competition for the remaining students. This competition 
may be based on quality, or it may be based on the ease of attaining a qualification. Seen in the light of more challenging prerequisites for students to gain HE eligibility combined with the potentially devastating effects of a bad reputation, the first strategy seems more likely; however, it cannot be ruled out that some HEIs may try to pursue the second. Regional HEIs may not be able to maintain the full range of programmes and may be forced to cooperate in consortia lest they perish. Like with the number of HEIs, a number of "trend faculties" established during the boom of the 1990s will be forced to close, either as a consequence of stricter accreditation and quality assurance requirements or because they will not be able to attract enough students. To the degree that this consolidation decreases the practice of teaching at more than one HEI, such a development may even contribute to the quality of teaching elsewhere.

All of these internal trends point towards further consolidation and decreasing internal quantity and possibly diversity, albeit arguably gaining in quality. In the macrosystem, the process towards European integration through the Bologna Process, student and staff mobility and joint research activities will make further internationalisation probable, although likely still on a relatively low level.

\section{Notes}

1. For instance, according to King $(2002,99)$, the share of Russians in the MSSR increased from 7\% in 1941 to $13 \%$ in 1989, and Russian became the native language of $4 \%$ of Romanians, $37 \%$ of Ukrainians, $7 \%$ of Gagauz, $18 \%$ of Bulgarians and $73 \%$ of Jews, and these numbers were higher among younger people (King 2002, 123).

2. The force behind this first initiative was professor Ion Groza, who in the past had benefited from a series of fellowships in the United States, France and the United Kingdom. On the basis of these first two student groups, the first private $\mathrm{HE}$ institutional structure was created by an official government decision within the auspices of a public institution. However, this private sub-division (named "private university") of a public university existed for only 3 years and had to suspend activity because of legal contradictions and personal opposition by university administration.

3. A noteworthy example of this knowledge transfer from Romania is the invitation of a Romanian professor to act as rector of the newly founded Academy of Economic Studies of Moldova.

4. Specifically, in 1990 the Pedagogical State Institute "Ion Creangă" became the Pedagogical State University "Ion Creanga"; in 1991 the Beltsy "Alecu 
Russo" State Pedagogical Institute was reorganised into the Beltsy "Alecu Russo" State University, the State Institute of Medicine to the State University of Medicine "N.Testemiteanu” (since 1996 the State University of Medicine and Pharmacy "N.Testemiteanu"), and the State Agrarian Institute "M. Frunze" of Moldova was nationalised and became the State Agrarian University of Moldova. In May 1992, the Tiraspol State Pedagogical Institute "T. Sevcenko" was reorganised into the Tiraspol State University. In 1993, the Polytechnical Institute "S.Lazo" of Moldova became the Technical University of Moldova. The two specialised HEIs in the field of culture and arts have supported a triple reorganisation: in 1993 the "Gavriil Musicescu" Moldovan State Conservatory became the Academy of Music "Gavriil Musicescu", which in 1999 merged with the Moldavian State Institute of Arts to become the State University of Arts in Moldova; in 2002 this university was reorganised into the Academy of Music, Theatre and Fine Arts of Moldova.

5. The 2014 Education Code allows graduates of other types of secondary education to participate in an external examination for the Baccalaureate upon application.

6. Accreditation results in recognition of an HEI as a "profile member" of the Academy of Science, which grants them the right to conduct independent research in a specific area. Alternatively, HEIs may become "affiliate members" of the Academy of Science, which allows them to conduct research in cooperation with the Academy of Science.

7. The exceptions are the Universities of Balti and Cahul.

8. A list of Moldovan HEIs can be found in Annex 6.1.

9. http://bloguvern.md/2013/11/11/rezultatele-finale-ale-examenuluide-bac-2013/

10. http://www.zdg.md/editia-print/social/peste-sase-mii-de-burse-pentrutinerii-din-r-moldova-care-doresc-sa-studieze-in-strainatate

11. The Ministry of Education lists all ongoing cooperation projects on its website: http://edu.md/ro/cooperare-internationala/

12. Some experts argue that in favour of long-term viability, quality and efficiency, the number of public HEIs should be reduced from the current 19 to only 7 , with 3 in the regions and 4 in the capital of Chisinau (Turcan et al. 2015).

\section{REFERENCES}

Ciurea, C., V. Berbeca, S. Lipcean, and M. Gurin. 2012. Higher Education System in the Republic of Moldova in the Context of the Bologna Process: 2005-2011. Chişinău: Soros Moldova-Foundation.

Cojocaru, V. Gh. 1995. Reforma învăţămîntului: orientări, obiective, direcţii. Chişinău: Ştiinţa. 
Cuciureanu, G. 2014. Country Reports 2013: Moldova//ERAWATCH Country Reports 2013: Moldova, EUR, Scientific and Technical Research Series. Vol. 26763. Luxembourg: Publications Office.

Galben, A., and A. Cogan. 2003. ULIM [Universitatea Libera Internationala din Moldova]: 1992-2002: pagini de istorie = ULIM: 1992-2002: stranicy istorii. Chişinău: [s. n.].

King, C. 2002. Moldovenii: România, Rusia și politica culturală. Chișinău: ARC.

National Bureau of Statistics of the Republic of Moldova. 2014. Educational in the Republic of Moldova: Statistical Publication, 2013/2014. http://www. statistica.md/public/files/publicatii_electronice/Educatia/Educatia_ RM_2014.pdf

Padure, L. 2009. The Politics of Higher Education Reforms in Central and Eastern Europe. Development Challenges of the Republic of Moldova. PhD Thesis. https://tspace.library.utoronto.ca/bitstream/1807/19157/6/Padure_ Lucia_200911_PhD_thesis.pdf

Republica Moldova Parlamentul. 1995. Law of Education of the Republic of Moldova. http://www.see-educoop.net/education_in/pdf/law_on_education_mol-enl-t04.pdf. Accessed 5 June 2014.

Ruffio, P, A. Giorgio, J. Gierach, and A.S. Ballart. 2012. Overview of the Higher Education Systems in the Tempus Partner Countries: Eastern Europe, Tempus Studies. Vol. 11. Luxembourg: Publications Office.

Secrieru, D. 2007. Integrarea sistemului educaţional din Republica Moldova in spaţiul european Studiu elaborat în cadrul Programului "Politici Educaţionale". Chișinău: Institutul de Politici Publice.

Smolentseva, A. 2012. Access to Higher Education in the Post-Soviet States: Between Soviet Legacy and Global Challenges. Unpublished.

Stati, V. 2002. Istoria Moldovei, Biblioteca Pro Moldova. Chișinău: Vivar-Editor.

The Parliament of the Republic of Moldova. 1995. Law of Education of the Republic of Moldova, No. 547-XII of 21.07.1995. http://www.see-educoop. net/education_in/pdf/law_on_education_mol-enl-t04.pdf

- 2014. Education Code of the Republic of Moldova, No. 152 of 17.07.2014. http://edu.gov.md/sites/default/files/education_code_final_ version.pdf

The World Bank. 1997. Staff Appraisal Report: Republic of Moldova General Education Project. http://www-wds.worldbank.org/servlet/WDSContent Server/IW3P/IB/1997/03/21/000009265_3980420170717/Rendered/ $\mathrm{PDF} /$ multi_page.pdf

Tiron, S,., V. Arion, M. Paiu, V. Scalnîi, and V. Stan. 2003. Higher Education in the Republic of Moldova, Monographs on Higher Education/UNESCO CEPES. Bucharest: UNESCO CEPES. 
Toderaş, N. 2012. The Governance of Higher Education System in Moldova: The Case of a Failed Institutional Change: Synopsis. http://www.doctorat.snspa. ro/sites/default/files/doctorat/nicolae\%20toderas/Abstract\%20\%20Eng.pdf

Turcan, R., and L. Bugaian, eds. 2015. Restructuring, Rationalizing and Modernizing Higher Education Sector in the Republic of Moldova. Chisinau: Cuvântul ABC.

Turcan, R.V., L. Bugaian, A. Niculita, A. Cotelnic, D. Pojar, and P. Todos. 2015. Draft Legislative Proposals. In Restructuring, Rationalizing and Modernizing Higher Education Sector in the Republic of Moldova, ed. R. Turcan and L.Bugaian, 11-43. Chisinau: Cuvântul ABC. http://vbn.aau.dk/ files/218934776/Restructuring_HE_in_Moldova.pdf.

Worden, E.A. 2014. Moldova: Challenges and Opportunities. In Education in Eastern Europe and Eurasia, Education Around the World, ed. N. Ivanenko, 47-64. London: Bloomsbury.

Yagodin, G.A., ed. 1990. Higher Education in the USSR. Bucharest: CEPES.

Lukas Bischof is a visiting research fellow and advisor at the Higher School of Economics (Moscow) and an associated consultant with CHE Consult (Berlin). Between 2011 and 2016 he worked as a consultant for universities, foundations, ministries of education and the European Commission. He has worked and published on the regulation and quality assurance of national and international higher education systems, institutional quality management and project management in higher education. As part of the Development of Quality Assurance in Higher Education in Moldova (QUAEM) project in Moldova, he supported universities and the government of the Republic of Moldova in the reform of the country's institutions of quality assurance.

Alina Tofan is a senior research fellow at the Moldova-Institut Leipzig at the University of Leipzig, Germany. Previously she was an associate professor at Moldova State University. She received a PhD in Philology from the Academy of Sciences of Moldova and a PhD in Philosophy from the University of Leipzig, Germany. She is author of numerous publications on literary and cultural history, sociolinguistics, migration and education. 
Open Access This chapter is distributed under the terms of the Creative Commons Attribution 4.0 International License (http://creativecommons.org/licenses/ by $/ 4.0 /)$, which permits use, duplication, adaptation, distribution and reproduction in any medium or format, as long as you give appropriate credit to the original author(s) and the source, provide a link to the Creative Commons license and indicate if changes were made.

The images or other third party material in this chapter are included in the chapter's Creative Commons license, unless indicated otherwise in a credit line to the material. If material is not included in the chapter's Creative Commons license and your intended use is not permitted by statutory regulation or exceeds the permitted use, you will need to obtain permission directly from the copyright holder.

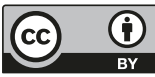

